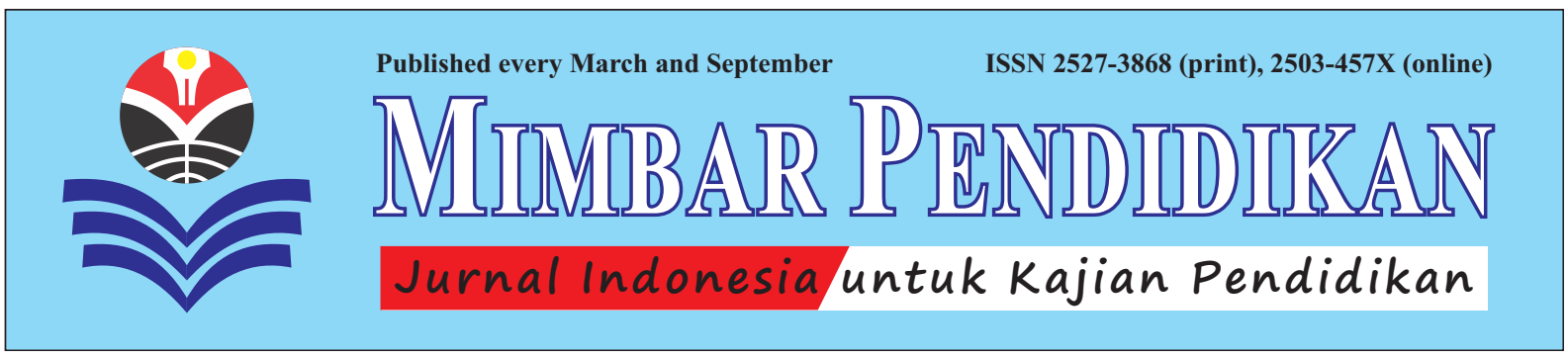

T.D. MUSHORIWA, V.T. MLANGENI \& M. KUREBWA

\title{
Assessing Attitudes of Primary School Teachers towards Free Primary Education in Swaziland: The Case of Shiselweni Region
}

\begin{abstract}
This study was designed to assess the attitudes of Primary School teachers towards FPE (Free Primary Education) recently introduced in Swaziland, with the ultimate aim of establishing how the teachers feel about the change given the increase in enrolments in the schools. The survey research design was employed. Data were sourced from 118 teachers (females $=50 \%$ ) through a semi-structured questionnaire and follow-up interviews. While data were largely analysed through the Likert scale analysis procedures described in this study, Cramer's $V$ was the statistic used to test if gender significantly influenced attitudes towards FPE. The study found that the majority of the teachers (73\%) had negative attitudes towards FPE mainly because of, among other things, large teacher-pupil ratios (1:70) which increased their workload; shortage of resources and infrastructure; being viewed as lowering educational standards; and the fact that the teachers were not consulted despite being the key implementers. Cramer's $V$ yielded an insignificant positive relationship (0.06) between gender and attitudes; and this meant that gender did not significantly influence the teachers' attitudes towards the introduction of FPE.

KEY WORD: Assessing; Teacher Attitudes; Free Primary Education; Increased Enrolments; Gender.
\end{abstract}

ABSTRAKSI: "Menilai Sikap Guru-guru Sekolah Dasar terhadap Pendidikan Dasar Gratis di Swaziland: Kasus Daerah Shiselweni”. Penelitian dirancang untuk menilai sikap guru-guru Sekolah Dasar terhadap PDG (Pendidikan Dasar Gratis) yang baru-baru ini diperkenalkan di Swaziland, dengan tujuan akhir menentukan bagaimana perasaan para guru tentang perubahan tersebut mengingat meningkatnya pendaftaran murid di sekolah. Desain penelitian survei digunakan dalam penelitian ini. Data bersumber dari 118 guru (perempuan $=50 \%$ ) yang diperoleh melalui kuesioner semi-terstruktur dan wawancara lanjutan. Data sebagian besar dianalisis melalui prosedur skala Likert, sedangkan V Cramer adalah statistik yang digunakan untuk menguji apakah jenis kelamin secara signifikan mempengaruhi sikap. Studi ini menemukan sebagian besar guru (73\%) memiliki sikap negatif terhadap PDG terutama karena, antara lain, besarnya rasio guru-murid (1:70) yang meningkatkan beban kerja; kurangnya sumber daya dan infrastruktur; dipandang akan menurunkan standar pendidikan; dan fakta bahwa guru tidak diajak urun-rembug meskipun sebagai pelaksana kunci. V Cramer menghasilkan hubungan positif yang tidak signifikan (0.06) antara gender dan sikap; dan ini berarti bahwa gender tidak berpengaruh secara signifikan terhadap sikap guru.

KATA KUNCI:Menilai; Sikap Guru; Pendidikan Dasar Gratis; Peningkatan Pendaftaran; Gender.

About the Authors: T.D. Mushoriwa, Ph.D. is a Full Professor at the University of Fort Hare in South Africa; V.T. Mlangeni is a Teacher at the Nhlangano Central High School in Swaziland; and M. Kurebwa is a Lecturer at the Zimbabwe Open University, Midlands, in Zimbabwe. Corresponding author is: tmushoriwa@ufh.ac.za

How to cite this article? Mushoriwa, T.D., V.T. Mlangeni \& M. Kurebwa. (2016). "Assessing Attitudes of Primary School Teachers towards Free Primary Education in Swaziland: The Case of Shiselweni Region" in MIMBAR PENDIDIKAN: Jurnal Indonesia untuk Kajian Pendidikan, Vol.1(2) September, pp.143-150. Bandung, Indonesia: UPI [Indonesia University of Education] Press, ISSN 2527-3868 (print) and 2503-457X (online).

Chronicle of the article: Accepted (July 16, 2016); Revised (August 17, 2016); and Published (September 30, 2016). 


\section{INTRODUCTION}

The key priority of the present study was to assess the attitudes of primary school teachers in the Shiselweni Region of Swaziland towards the recently introduced the FPE (Free Primary Education). It is important to study the attitudes of teachers as the change is being introduced, because attitudes have been found to influence the extent to which changes have been implemented (Mushoriwa, 2001). For R.G. Berlach (2004), the only way to test if a new approach or programme in education works is to take it to the teachers and ask questions (Berlach, 2004).

Ungerleider, as captured in T.D. Mushoriwa (2001), contend that when teachers resist change, the change will be implemented with considerable social dislocation and high social cost (Mushoriwa, 2001). It is, therefore, critical to study the teachers' attitudes in the initial stages of the programme, so that if teachers are found to have negative attitudes, steps can be taken to remedy the situation. To the writers, no such study has been conducted in Swaziland since the introduction of FPE in 2010 .

A study done by N.H. Simelane (2011), that involved parents, showed parents complaining about falling standards in schools, with many parents attributing this to large class sizes and lack of resources (Simelane, 2011). The newspaper of Swazi News, on 31 March 2012, contained letters written to the Editor by some parents complaining about FPE had the heading "No Quality Education with FPE" (Swazi News, 31/3/2012:16).

Reasons given excluded the role the teacher can play yet studies, e.g. R.G. Berlach (2004), have shown that where teachers do not support introduced changes, those changes often crumble and fail (Berlach, 2004). It is this backdrop that triggered the present study.

\section{BACKGROUND AND \\ LITERATURE REVIEW}

International organizations, such as the UNESCO (United Nations for Education, Scientific and Cultural Organization) in 2005 and the WB (World Bank) in 2009, have urged all governments and nations to introduce Universal Free Primary Education in line with the Millenium Development Goals (UNESCO, 2005; and WB, 2009). Education is seen as critical in spearheading national development. This faith in education as an urgent of change has seen many countries, including Swaziland, heavily investing in education.

M. Sithole (2011), the then Minister of Finance in Swaziland, indicated that E 94.7 (R 94.7) million was needed to fund the FPE (Free Primary Education) programme yearly from E 29 (R 29) million per year (Sithole, 2011:13). The belief is that this heavy investment in education will yield massive socio-economic returns for the nation. Among others, some of the objectives were to remove barriers (e.g. financial) and to increase access to primary education; to eliminate all forms of disparities and inequalities in primary education; to eradicate illiteracy and alleviate poverty; and equip every child with skills and knowledges (Government of Swaziland, 2010).

While the above are noble objectives, the extent to which teachers accept this change has not been evaluated. The Swaziland National Association of Teachers, in 2010, once warned the Ministry of Education and Training about going ahead with the programme without consulting them. The Association's efforts to meet the Ministry over the programme were turned down and this infuriated teachers. To the writers' knowledge, no such meeting ever occurred. ${ }^{1}$

R.W. Griffin (2002) argues that if stakeholders are not to resist change, they

${ }^{1}$ See, for example, news on "SNAT Warns of Chaos" in Times of Swaziland. Mbabane, Swaziland: Government Printers, on 12 January 2010, p.2. 
must be involved in the planning of the change or, at least, they must be educated about the need for and expected results from the change, yet in this case, the Ministry actually refused to meet the teachers (Griffin, 2002). The newspaper of Swazi News, on 10 August 2012, quotes the Minister of Education and Training as saying, after being criticised by some Senators, as follows:

Consultation was not done extensively with principals and imiphakatsi (communities). I agree on that one, it was an oversight (MET Swaziland, 2012:2).

No mention of teachers was made yet they are the chief implementers. Soon, school principals also began to complain about the inadequacy of the money paid by the Government - which made it difficult for them to start new projects or sustain old projects since the introduction of FPE (Free Primary Education).

R.W. Griffin (2002) argues that if change is introduced without adequate consultation, resistance, which may be manifest (active) or salient (passive) may result. Stakeholders should be involved in the planning and execution of the change, so that they too understand and appreciate the need for the change (Griffin, 2002). Involving stakeholders achieves a greater level of motivation, open lines of communication, a free, honest and complete flow of information, a greater awareness of grassroots problems ( $c f$ Griffin, 2002; and Deventer \& Kruger, 2010). For R.W. Griffin, people are usually committed to plans that they have helped to shape (Griffin, 2002).

Clearly in Swaziland, the relevant stakeholders were not consulted; and in the case of teacher representatives, they were further refused audience with the Minister - fearing criticism. From the writers' point of view, it would appear that Swaziland was not ready for FPE. Given that Swaziland is currently going through a difficult time
- a deteriorating economy; increasing unemployment; increasing signs of social and political unrest; escalating crime rate and the tragic impact of HIV/AIDS (Human Immunodeficiency Virus/Acquired Immune Deficiency Syndrome); and one wonders whether it was the right time for Swaziland to introduce FPE.

Rapid enrolments in schools, further, challenged an already weak education system due to the economic meltdown the country is experiencing. The rapid quantitative expansion did not match the expected qualitative expansion of the education system. Schools began to experience acute shortages of teachers, classrooms, teaching/learning materials, teacher accommodation, etc.

It is against this background that the present study set out to assess teacher attitudes towards the introduced FPE in Swaziland given that attitudes, which include beliefs, convictions, desires, feelings, hopes, judgments, opinions, and values people have towards specific issues greatly influence human behaviour and actions (Mushoriwa, 2001).

\section{METHOD}

Research Design. The study used the survey research design. The design was appropriate for the study, because surveys have the advantage of being used with relatively large samples (Mushoriwa, 2011), as was the case in the present study $(\mathrm{n}=118)$. Large samples imply that data are collected from many people (instead of from just a few), making the results more representative and therefore credible. Surveys also allow the collection of detailed descriptions of existing phenomena with the intent of employing the data to justify current conditions and practices or to make more intelligent plans to improve them (Mushoriwa, 2011).

For J.W. Creswell (2007), surveys are very appropriate for examining practices, trends, attitudes, opinions, and values of a population towards a given phenomenon 
(Creswell, 2007). Surveys are an effective tool for determining the opinions, attitudes, preferences, and perceptions of people (Dike, 1998). The current study aimed at assessing the attitudes of primary school teachers towards the recently introduced FPE (Free Primary Education) in Swaziland with a view to identifying areas that need attention.

The survey design also allowed the triangulation of data collecting instruments (questionnaires and follow-up interviews) for better understanding of the phenomenon under study (Maree ed., 2010); and, therefore, for better research results (Creswell, 2007). For W.M. Trockim (2006), the best hope for achieving objectivity in research is by triangulating multiple fallible methods as was the case in the present study (Trockim, 2006).

Participants. One hundred and eighteen teachers (female $=50 \%$; mean age $=29.9$; and $\mathrm{SD}=1.6$ ) were recruited for the study through stratified random sampling to ensure that the groups the researcher was interested in (males and females) were equally represented. This was critical since the study was also interested in the interaction between gender and attitude. The sample $(\mathrm{n}=118)$ was considered representative, because according to D.B. Van Dalen (1979), if you are dealing with descriptive research (which this study is), anything from $10 \%$ to $20 \%$ of the population is representative (Van Dalen, 1979).

One hundred and eighteen teachers out of 588 teachers in the region are $20 \%$; hence, the sample is representative. For J.W. Creswell (2007), careful sampling improves the validity of research results, while a representative sample enhances the credibility of research results (Creswell, 2007).

Instruments. A 20-item semi-structured questionnaire and follow-up interviews were the instruments used to source data from the participants. The questionnaire used the Likert scale (Agree $=$ A; Strongly Agree $=\mathrm{SA}$; Undecided $=\mathrm{U}$; Disagree $=\mathrm{D}$; and Strongly Disagree $=$ SD) and open-ended items which involved giving reasons for giving certain responses in the Likert scale. The questionnaire, because of its anonymity, was appropriate for this study which not only covered a wide geographical area, but also dealt with a very sensitive issue for civil servants, such as teachers- attitudes towards a government-initiated change. Without using a questionnaire, many respondents could have feared to express views unpopular with the government for fear of victimisation.

Follow-up interviews, done with 16 teachers involved in the study, probed into subtle issues and unexpected responses raised in the questionnaire. These interviews were also useful in seeing the motivations of respondents and their reasons for responding the way they did.

Validity and Reliability. The questionnaire, constructed by the researchers, was tested for both validity and reliability using the InterRater Method. Six experts were asked to check the suitability of the questionnaire as a measure of attitudes. The same experts were asked to score the questionnaire (out of 10) and these ratings were correlated, yielding a coefficient of 0.8 . This shows that to a very high degree, the raters agreed that the questionnaire was reliable.

The questionnaire was further testrun with 20 teachers to see if it worked as intended. After minor adjustments and modifications, the questionnaire was adopted for use with the study sample. Thus, the use of an instrument which has fidelity is of utmost importance in collecting valid and reliable data. For J.W. Creswell (2007), validity in quantitative research can be improved through careful sampling, appropriate instrumentation, and appropriate statistical treatment of the data (Cramer's V is very appropriate for bivariate analysis of nominal data) as was the case in the present study (Creswell, 2007).

Data Analysis. Data were analysed using frequencies, percentages, and Cramer's V. 
Table1:

Scoring the Likert Scale

\begin{tabular}{lccccc}
\hline & SA & A & U & D & SD \\
\hline Positive statement & 5 & 4 & 3 & 2 & 1 \\
Negative statement & 1 & 2 & 3 & 4 & 5 \\
\hline
\end{tabular}

The Likert scale used attitudinal data analysis procedures described in many such studies (cf Rajecki, 1982; and Mushoriwa, 2001). Percentages and Cramer's V coefficient were used to report the results.

About scoring the Likert scale. The Likert scale, which, as already seen, used Agree (A); Strongly Agree (SA); Undecided (U); Disagree (D); and Strongly Disagree (SD) was scored as shown in table 1.

Following attitudinal data analysis procedures used elsewhere (Rajecki, 1982), statements were first classified into positive and negative. Positive statements were then scored 5 for SA (Strongly Agree) down to 1 for SD (Strongly Disagree), while negative statements were scored 1 for SA up to 5 for SD.

Item scores for each respondent were next added to obtain a total score. Since the questionnaire had 20 items, there was a maximum possible score of $100(5 \times 20)$ and a necessary minimum score of 20 ( 1 x 20). To see whether the respondents' attitudes were positive or negative, a score above the mid-way of the maximum possible score $(100 \div 2=50)$ was regarded as positive while scores below that were regarded as negative. The neutral point (50) was left out in order to make the results directional (Fishbein, 1975).

Since in this study high scale scores meant a favourable attitude towards the change introduced and low scale scores meant an unfavourable attitude, it means that overall, if there are more high scale scores than low scale scores, we conclude that the change is appreciated; but if there are more low scale scores, we conclude that the teachers have a negative attitude towards the introduction of FPE (Free Primary Education).

\section{RESULTS AND DISCUSSION}

After checking the data for internal coherence and consistency, they were collated, transferred to coding sheets and key-punched for analysis. The results were as follows:

Total No. of Low Scale Scores (20-49) $=86(73 \%)$.

Total No. of High Scale Scores (51-100) = 32 (27\%).

As shown above, the total number of low scale scores $(73 \%)$ is more than the total number of high scale scores (27\%). This shows that the majority of primary school teachers $(73 \%)$ have an unfavourable attitude towards the introduction of FPE (Free Primary Education) in Swaziland.

The 20-questionnaire items were themselves taken as rating scales and, as such, were analysed individually. Only results of items considered critical to the study are reported here to minimise space.

The majority of teachers $(86.4 \%)$ indicated that they understood what FPE is all about and what it is meant to achieve (item 1). However, all the teachers (100\%) expressed anger that the Government did not consult them at all (item 2). In an interview, one teacher angrily commented, as follows:

We are the key implementers yet, they don't want to take our views. They undervalue us, because they think that we don't have knowledge. We can also retaliate by undermining the programme (interview with Respondent A, 2/9/2015).

This shows that it is important to involve teachers all the way from policy formulation to implementation, if they are to uphold the change. For Ungeleider, as captured in T.D. Mushoriwa (2001), when teachers resist 
Table 2:

Crosstab of Gender and Attitude $(\mathrm{n}=118)$.

\begin{tabular}{lccc}
\hline & Gender & N & \% Attitude \\
\hline Males & 59 & 54.1 \\
Females & 59 & 45.9 \\
\hline Total & $\mathbf{1 1 8}$ & $\mathbf{1 0 0}$ \\
\hline
\end{tabular}

Note: Cramer's V $=0.06$.

change, the change will only be implemented with considerable social dislocation and high social cost (Mushoriwa, 2001).

For R.W. Griffin (2002), although goals and plans may be initiated at high levels, they must be communicated to all stakeholders, because people are usually committed to plans they have helped shape. Perhaps if the Government had consulted them, FPE (Free Primary Education) could have been a welcome move by the teachers. This may explain why FPE was, overall, viewed negatively despite the fact that $55.9 \%$ of the teachers (item 3 ) felt that it was a good idea to introduce FPE, arguing that it increases literacy rates, reduces crime, helps people to acquire knowledge and skills which they can use to improve their standards of living, and that it enables people to make sound decisions.

Those who felt that it was not a good idea to introduce FPE (44.1\%) expressed the view that it is a waste of state funds given the huge budget for HIV/AIDS (Human Immunodeficiency Virus/Acquired Immune Deficiency Syndrome) and the general economic decline in the country. One teacher commented, as follows:

Since FPE was introduced, Swaziland has sunk into deep financial crisis. Investing so much in primary education, where pupils hardly acquire meaningful skills and knowledge, may be a waste of the country's meagre resources unless such children go up to tertiary institutions (interview with Respondent B, 9/9/2015).

About 94\% (item 17) of the teachers also felt that both the Government and the Ministry of Education and Training were not ready for FPE (Free Primary Education) as evidenced by the acute shortages of teaching/ learning resources, schools, classrooms, teachers, etc. Congested classrooms due to large teacher-pupil ratios (1:70) were accused of causing education standards to fall (item 17). One teacher commented, as follows:

\section{Pass rates in our schools have been declining year after year, since the introduction of FPE. Are we not sacrificing the education of some of our children? Teachers are under serious pressure from parents-pressure of high performance expectation despite the limited resources (interview with Respondent C, 16/9/2015).}

These sentiments may be suggestive of the direction FPE (Free Primary Education) in Swaziland may eventually take. In item $20,59.3 \%$ of the teachers felt that they would rather send their own children to private schools, which charge fees but maintain good educational standards. One teacher commented, as follows:

Don't you know that these poor conditions and limited resources in public schools can limit the performance of even the best teachers and pupils? (interview with Respondent D, 23/9/2015).

So, it would appear that many teachers in this study showed a negative attitude towards the introduction of FPE (Free Primary Education) mostly because of, among other reasons, not being consulted, inadequate resources, congested classrooms, and work overload.

Testing the Hypothesis. The study hypothesised that the teachers' attitudes 
towards FPE (Free Primary Education) would be influenced by gender. To explore this hypothesis, Cramer's V was used. See table 2.

Cramer's V (0.06) shows a very low positive relationship between gender and the teachers' attitudes towards the introduction of FPE (Free Primary Education). Although male teachers are more accepting (54.1) to the change than female teachers (45.9), the difference is statistically so small, that it is considered insignificant. Therefore, since no significant gender-attitude interaction was yielded, one can be justified to conclude that gender did not significantly influence the teachers' attitudes towards the introduction of FPE in Swaziland.

\section{CONCLUSION}

In conclusion, it should be noted that teachers in this study had negative attitudes towards the introduction of FPE (Free Primary Education) mostly because, among other things, it resulted in: overcrowdedness in schools and classrooms; shortages of resources and infrastructure; work overload for the teachers; lowering of educational standards; and, lastly, teachers were infuriated by not being consulted. It is important to note that these attitudes held by teachers may have serious psychological effects on both pupils and society at large regarding the value they will attach to such an education system; hence, the need to address the teachers' concerns.

Based on the findings of the study, the following recommendations were made: (1) the Ministry of Education and Training should reduce teacher-pupil ratios and avail more resources and infrastructure; and (2) a large scale study involving all primary school teachers in the country might shed more light on the teachers' attitudes towards FPE. ${ }^{2}$

\footnotetext{
${ }^{2}$ Statement: We would like to declare that this article is our original work; so, it is not product of plagiarism and not yet also be reviewed and published by other scholarly journals.
}

\section{References}

Berlach, R.G. (2004). "Outcome-Based Education and the Death of Knowledge". Paper presented at the Australian Association of Research Conference at the University of Melbourne, Victoria, Australia, on 28 November - 2 December.

Creswell, J.W. (2007). Educational Research: Planning, Conducting, and Evaluating Quantitative and Qualitative Research. New Jersey: Prentice Hall.

Deventer, I.V. \& A.G. Kruger. (2010). An Educator's Guide to School Management Skills. Pretoria: Van Schaik.

Dike, H. (1998). The ABC of Research Methods in Education. Port Harcourt: Pam Unique.

Fishbein, M. (1975). Belief, Attitudes, Intention, and Behaviour. Manila, Philippines: Addison Wesley.

Government of Swaziland. (2010). Swaziland Free Primary Education Act. Mbabane, Swaziland: Government Printers.

Griffin, R.W. (2002). Management. New York: Houghton Mifflin.

Interview with Respondent A, One of the Primary School Teachers, in Shiselweni, Swaziland, on 2 September 2015.

Interview with Respondent B, One of the Primary School Teachers, in Shiselweni, Swaziland, on 9 September 2015.

Interview with Respondent C, One of the Primary School Teachers, in Shiselweni, Swaziland, on 16 September 2015.

Interview with Respondent D, One of the Primary School Teachers, in Shiselweni, Swaziland, on 23 September 2015.

Maree, K. [ed]. (2010). First Steps in Research. Pretoria: Van Schaik.

MET [Minister of Education and Training] Swaziland. (2012). "No Adequate Consultation" in newspaper of Swazi News. Mbabane: African Echo, August 10, p.2.

Mushoriwa, T.D. (2001). “A Study of the Attitudes of Primary School Teachers in Harare towards the Inclusion of Blind Children in Regular Classes" in British Journal of Special Education, 28(3), pp.142-147.

Mushoriwa, T.D. (2011). Helping You Do Research in the Early Stages. Berlin: Lambert Academic Publishing Co.

News on "No Quality Education with FPE" in newspaper of Swazi News. Mbabane, Swaziland: African Echo, on 31 March 2012, p.16.

News on "SNAT Warns of Chaos" in Times of Swaziland. Mbabane, Swaziland: Government Printers, on 12 January 2010, p.2. 
Rajecki, D.W. (1982). Attitudes: Themes and Advances. Massachusetts: Sinauer Associates Publishers.

Simelane, N.H. (2011). "Free Primary Education Implementation in Swaziland and SouthWest African Countries: A Lesson that Can be Learned". Unpublished Master's Thesis. Luyengo, Swaziland: The University of Swaziland.

Sithole, M. (2011). "E 94.7 Million for Free Primary Education" in newspaper of Swazi News. Mbabane, Swaziland: African Echo, February 19, p.13.
Trockim, W.M. (2006). The Research Methods Knowledge Base. New York: Prentice Hall.

UNESCO [United Nations for Education, Scientific and Cultural Organization]. (2005). Ensuring Access to Education for All. Paris: UNESCO Publication.

Van Dalen, D.B. (1979). Understanding Educational Research: An Introduction. New York: McGraw Hill.

WB [World Bank]. (2009). Abolishing School Fees in Africa: Lessons from Ethiopia, Ghana, Kenya, Malawi, and Mozambique. Geneva: World Bank. 